\title{
Spore Dispersal Patterns of Fusarium circinatum on an Infested Monterey Pine Forest in North-Western Spain
}

\author{
Miloň Dvořák ${ }^{1, *}$, Patrik Janoš ${ }^{2}$, Leticia Botella ${ }^{1}$, Gabriela Rotková ${ }^{3}$ and Rafael Zas ${ }^{4}$ \\ 1 Phytophthora Research Centre, Department of Forest Protection and Wildlife Management, \\ Faculty of Forestry and Wood Technology, Mendel University in Brno, Zemědělská 1, 61300 Brno, \\ Czech Republic; letibotella@gmail.com \\ 2 Department of Forest Protection and Wildlife Management, Faculty of Forestry and Wood Technology, \\ Mendel University in Brno, Zemědělská 1, 61300 Brno, Czech Republic; patrickjan05@gmail.com \\ 3 Department of Experimental Biology, Masaryk University, Kamenice 735/5, 62500 Brno, Czech Republic; \\ gabcarot@gmail.com \\ 4 Department of Forest Genetics and Ecology, Biological Mission of Galicia (MBG-CSIC), \\ Apdo. 28, 36080 Pontevedra, Spain; rzas@mbg.csic.es \\ * Correspondence: milon.dvorak@mendelu.cz; Tel.: +420-545-13-4120
}

Received: 30 September 2017; Accepted: 7 November 2017; Published: 15 November 2017

\begin{abstract}
The airborne inoculum of Fusarium circinatum Nirenberg \& O'Donnell, the fungal pathogen causing Pine Pitch Canker (PPC), is one of the main means of spread of the disease in forest stands and forest nurseries. Since this world-wide known pathogen was introduced in Europe, its biology in this newly infested area still remains scarcely known. To shed more light on this topic, we set up an experiment on a naturally PPC infested forest of Monterey pine in Galicia (NW Spain) with the following two goals: (i) to describe the seasonal spore dispersal pattern during one year of regular sampling and (ii) to assess the spatial spore dispersal pattern around the infested plot. Portable rotating arm spore traps were used and complemented with meteorological measurements. The abundance of F. circinatum spores in the samples was assessed by quantitative PCR (qPCR) with a hydrolysis probe. The results showed almost permanent occurrence of the air inoculum throughout the whole year, being detected in 27 of the 30 samplings. No clear temporal trends were observed, but a higher air inoculum was favoured by previous lower air temperatures and lower leaf wetness. Conversely, neither rainfall nor air humidity seemed to have any significant importance. The spatial spread of the inoculum was noted to be successful up to a distance of $1000 \mathrm{~m}$ in the wind direction, even with winds of just $5 \mathrm{~m} \cdot \mathrm{s}^{-1}$. Our study shows that rotating arm spore traps combined with qPCR may be an efficient tool for F. circinatum detection.
\end{abstract}

Keywords: pine pitch canker; Galicia; spore trap; air sampling; qPCR; seasonal dynamics

\section{Introduction}

Fusarium circinatum Nirenberg \& O'Donnell [1] (teleomorph Gibberella circinata Nirenberg \& O'Donnell) is the causal agent of the disease called Pine Pitch Canker (PPC), which affects up to 60 species of pines and Douglas fir (Pseudotsuga menziesii (Mirb.) Franco) [2]. In adult trees, the main symptoms of PPC are pitch soaked cankers on the main stem or big lateral branches [3], which may girdle both stem and branches. Roots, shoots, flowers, cones and seeds may result infected as well. PPC is often responsible for the retarded growth of mature trees and massive mortality of saplings in forest nurseries, causing serious economic losses [4].

Originating naturally in Central America [5], nowadays, F. circinatum has a worldwide distribution. Since its discovery in the USA in 1946 [6], it has been introduced to Japan [7], South Africa [8], South Korea [9], and Chile [10]. In 2005, it was reported in Spain [11], although it was observed in 
forest nurseries in the Basque country (Spain) in 1997 [12]. After that, F. circinatum rapidly appeared in other European countries, including France [13], Italy [14] and Portugal [15], alarming the European forest authorities. Nowadays, the pathogen is mentioned in the EPPO (European and Mediterranean Plant Protection Organization) A2-list as a quarantine organism present in the area of EPPO countries but not yet widely distributed [16]. Although apparently eradicated in Italy and France, it is still present in Portugal and Spain [17].

Transport of infected plant material seems to be the most effective way for PPC introduction, especially for long distances [18]. In forest stands, however, the pathogen can also spread by natural means. F. circinatum is a seedborne pathogen that can survive both superficially and internally in seeds [19], favouring the spread of the disease to the following pine generation. Its macro- and microconidia (asexual spores) are also spread by wind, water and insect vectors that infect trees through weather-related injuries and wounds associated with insect feeding and pruning [20-23].

Understanding the temporal and spatial spore dispersal is, thus, critical for fine tuning efficient control measures that limit the disease expansion. Such knowledge could be efficiently applied to design silvicultural guidelines aimed at minimizing the risk of infection of trees by the pathogen. As an example, Gonthier et al. [24] suggested a shift in timing of thinning operation in Norway spruce forests according to the temporal pattern of spore dispersal of Heterobasidion parviporum Niemelä \& Korhonen. Furthermore, environmental factors determining the temporal dispersal of a pathogen play a crucial role in the estimation and modelling of future spread and extent of possible epidemics $[23,25]$ and possible development of the disease under global climate changes [23,26,27].

Understanding the temporal and spatial spore dispersal is, thus, critical for fine tuning efficient control measures that limit the disease expansion. Such knowledge could be efficiently applied to design silvicultural guidelines aimed at minimizing the risk of infection of trees by the pathogen. As an example, Gonthier et al. [24] suggested a shift in timing of thinning operation in Norway spruce forests according to the temporal pattern of spore dispersal of Heterobasidion parviporum Niemelä \& Korhonen. Furthermore, environmental factors determining the temporal dispersal of a pathogen play a crucial role in the estimation and modelling of future spread and extent of possible epidemics $[23,25]$ and possible development of the disease under global climate changes [23,26,27].

The seasonal spore dispersal pattern of $F$. circinatum has been previously investigated in northern California (USA), where more spores were detected in October than in June and July [18]. This pattern was confirmed by the whole year sampling carried out by Garbelotto et al. [28], who detected the highest spore presence in the same area during the cold and wet weather from November to March. In San Francisco, Garbelotto et al. [28] showed the importance of sea fog, which can alleviate the water deficit during dry periods in summer, and enhance the fungal sporulation. Wingfield et al. [29] emphasize, however, that the life cycle of the pathogen may largely vary among different geographical areas, host species and particular conditions of forest stands. To the best of our knowledge, studies exploring the temporal dynamics of spore dispersal in Europe are lacking.

Spatial spread of F. circinatum spores in forest stands has only been partly investigated. Although it is not known how far the airborne spores may be dispersed [2], it was concluded that the conidia of F. circinatum have limited flight distance potential [2,23,28]. According to Garbelotto et al. [28], its dispersal is influenced little by the wind direction and speed. These authors did not find differences in spore occurrence 100, 200 and $300 \mathrm{~m}$ from the infested stand. In any case, from an epidemiological point of view, long distance transfer of the spores is probably less important due the possibly low viability of the thin walled and hyaline spores [2].

The main aim of the present study was to investigate the seasonal spore dispersal pattern of F. circinatum, which may help to develop effective control measures of PPC in European pine forests. Particularly, the objectives of this study were (i) to describe the seasonality of the occurrence of F. circinatum spores during a one-year sampling in an infested locality in Galicia (north western Spain), (ii) to investigate the correlation between air inoculum quantity and meteorological variables and (iii) to investigate the spatial patterns of spore dispersal and the influence of the wind in the spread 
of the inoculum. To this end, we used an active air-sampling trapping system especially designed for fungal spore assessments, but never used before with F. circinatum. Quantification of the spores collected in these traps was done by quantitative PCR (qPCR) techniques. Two surveys were conducted: one designed for covering the within-annual variation in spore abundance, and one designed for analysing the spatial dispersal around the infested spot.

\section{Material and Methods}

\subsection{Sampling Area}

The sampling was conducted within a 40-year-old forest stand of Pinus radiata D. Don with some Pinus pinaster Aiton close to Ponte Caldelas, Galicia, Spain, 440-480 m a.s.l. (GPS coordinates of the centre: $42.376249^{\circ},-8.478177^{\circ}$ ). The pine stand covers an area of approximately 7.5 ha and it is isolated from other pine forests due to a large forest fire that occurred in 2006. Infection of F. circinatum at this stand was confirmed in 2006 by the Regional Forest Service (Xunta de Galicia). Although not formally checked, F. circinatum appeared to be infecting most of the adult pine trees within the stand. During the experiment, typical symptoms (needle wilting, brown flagging, pitching on the stems, and dieback) were apparent on many trees, especially at the edge of the stand, and particularly in its north-west end, where several trees even died during the course of the experiment.

\subsection{Spore Traps}

Actively rotating arm spore traps ROTTRAP 120 (Miloň Dvořák, Boršov nad Vltavou, Czech Republic) were used for all the experiments. The construction of this spore trap is based on the description of Perkins and Leighton [30] and McCartney et al. [31]. An electric motor rotates $2400 \mathrm{rpm}$ with a $0.8 \mathrm{~mm}$ thick U-shaped, square section wire (Figure 1). The vertical impactors of $50 \mathrm{~mm}$ in length distanced at $200 \mathrm{~mm}$ were covered for every sampling with a new double-sided non-woven tape (Tesa SE, Norderstadt, Germany). Covering the front side (according to the direction of rotation) of each impactor, the spore trap provided an impaction area of $80 \mathrm{~mm}^{2}$. According to equations of Noll [32], the spore traps sample the air at a speed of $120 \mathrm{~L} \cdot \mathrm{min}^{-1}$ with almost a 100\% collecting efficiency for particles bigger than $7.18 \mu \mathrm{m}$. Each trap was mounted $1.4 \mathrm{~m}$ high and powered by a $12 \mathrm{~V} / 19 \mathrm{Ah}$ battery.

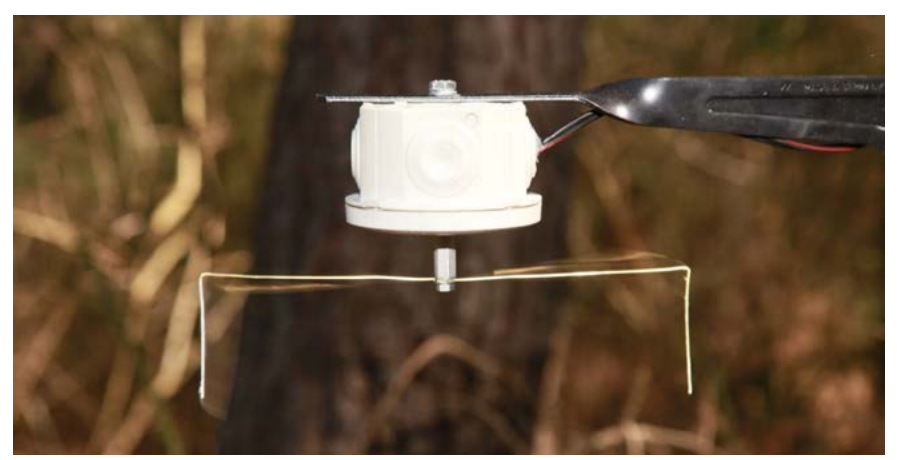

Figure 1. Running spore trap (ROTTRAP 120) coated with double-sided tape on the impaction side of the square section wire.

\subsection{Seasonal Dynamics Sampling}

To follow the seasonal dynamics of the F. circinatum inoculum, three spots labelled as A (GPS: $\left.42.378014^{\circ},-8.477219^{\circ}\right), \mathrm{B}\left(42.376249^{\circ},-8.478177^{\circ}\right)$ and $\mathrm{C}\left(42.374474^{\circ},-8.479641^{\circ}\right)$ were established within the 7.5 ha infested pine stand close to apparently infected trees. In each spot, one spore trap was installed at least two times per month from April 2016 until March 2017, resulting in 30 samplings. In each sampling, the spore traps were running for $48 \mathrm{~h}$. 
To monitor the air inoculum splashed by raindrops, each sampling with the spore trap was accompanied by the sampling of the rain water close to the soil surface. For that purpose, a $90 \mathrm{~mm}$ Petri dish was left open during the 48-h sampling period. The exposed tapes and $1 \mathrm{~mL}$ of rain water were stored in 2-mL microtubes at $-20^{\circ} \mathrm{C}$ before further processing. The two tapes of each spore trap were mixed and stored together in a single microtube.

\subsection{Spatial Spread Sampling}

For the analysis of the inoculum spatial spread, 11 spore traps were used. The spore traps were installed following a Latin cross arrangement with the elongated arm following the forecasted wind direction. Eight of the spore traps were established 50 and $500 \mathrm{~m}$ from the last tree of the infested forest stand in each of the four orthogonal directions. Additionally, in the direction following the wind, two more spots were established at 100 and $1000 \mathrm{~m}$ from the last infected tree. Finally, in the middle of the infested stand, the spot B described in the previous section, was also sampled. For each 48-h sampling period, the forecasted wind direction was previously taken into account to orient the main arm of the experimental design. The wind forecasts were obtained from (https: / / www.windguru.com/) and the real values of wind speed and direction were downloaded after the sampling from the same source. Data from Pontevedra, $15 \mathrm{~km}$ from the sampling site and the closest continuously measuring spot at these websites, were used. Four samplings (around one per week) were carried out in September-October 2016.

\subsection{Meteorological Measurement}

Meteorological data were recorded every $15 \mathrm{~min}$ throughout the whole sampling year using an automatic climatic station (AMET, Velké Bílovice, Czech Republic) placed in the spot A. The station, established at a height of $1 \mathrm{~m}$, recorded air temperature and humidity, precipitation and leaf wetness. Leaf wetness was measured as an electric resistance of a filter paper placed between two electrodes.

\subsection{DNA Extraction}

DNA was extracted from all the samples together with an empty microtube as a negative control of extraction. Spores were disrupted and homogenized directly in a Mixer Mill MM400 (Retsch, Haan, Germany), using a mixture of $0.4 \mathrm{~g}$ of $0.1 \mathrm{~mm}$ balotina beads and $250 \mu \mathrm{L}$ of $0.1 \%$ Nonidet P40 - substitute (AppliChem, Darmstadt, Germany). The homogenization was performed for 10 min at $30 \mathrm{~Hz}$. For further processing, the DNEasy Plant Mini Kit (Qiagen, Valencia, CA, USA) was used according to the manufacturer's instructions, except the incubation with AP1 buffer, which was prolonged to $60 \mathrm{~min}$. In the last step, DNA of each sample was eluted only once with $100 \mu \mathrm{L}$ of preheated elution buffer previously incubated for $10 \mathrm{~min}$.

\subsection{Quantitative PCR}

Direct specific qPCR was performed using a LightCycler ${ }^{\circledR} 480$ Instrument II (Roche Diagnostics, Basel, Switzerland), TaqMan Universal PCR Master Mix (Applied Biosystems, Foster City, CA, USA) and specific primers and a probe [33] according to the manufacturer's instructions (pre-incubation: $10 \mathrm{~min}$ at $95{ }^{\circ} \mathrm{C}$ followed by 45 cycles of denaturation: $10 \mathrm{~s}$ at $95{ }^{\circ} \mathrm{C}$; annealing: $30 \mathrm{~s}$ at $60{ }^{\circ} \mathrm{C}$; extension: $1 \mathrm{~s}$ at $72{ }^{\circ} \mathrm{C}$ - single acquisition mode). The reaction mixture was as follows: $0.2 \mu \mathrm{L}$ of each primer (final concentration $400 \mathrm{nM}$ ), $0.2 \mu \mathrm{L}$ of TaqMan probe (200 nM), $5 \mu \mathrm{L}$ of TaqMan Universal PCR Master Mix, $1.9 \mu \mathrm{L}$ of sterile deionized water and $3 \mu \mathrm{L}$ of template DNA.

Every reaction was performed in three technical repetitions together with a positive control, negative control of isolation and also a negative control of qPCR reaction containing the master mix without template DNA.

The concentrations of F. circinatum DNA in the samples (hereafter $\mathrm{CN}$ ) were expressed as numbers of copies of the target sequence in $1 \mu \mathrm{L}$ of template DNA. CNs were determined using a standard curve that was generated by different concentrated aliquots of a plasmid pCR $^{\mathrm{TM}} 4-\mathrm{TOPO}^{\circledR}$ vector (Invitrogen, 
Carlsbad, CA, USA) with an insert of the target gene (fragments were amplified with the primers described above). All reactions were performed in LightCycler ${ }^{\circledR} 480$ software (Roche Diagnostics).

\subsection{Statistical Methods}

Average $\mathrm{CN}$ across the three sampling spots (A, B and C) was calculated for every sampling and used for further analyses. Relationships between $\mathrm{CN}$ and meteorological variables (daily averages of air temperature, relative humidity, leaf wetness and precipitation) were tested. Because the analysed variables were not normally distributed even after log-transformation, only non-parametric tests were used. Spearman's correlation was calculated between $\mathrm{CN}$ of each sampling and the average value of each of the meteorological variables measured 3, 7, 14, 21 and 28 days before the end of the sampling. All the statistical analyses were performed in STATISTICA 12 (StatSoft, Tulsa, OK, USA).

\section{Results}

\subsection{Seasonal Spore Dispersal}

The results of the sampling are shown in Figure 2. In total, F. circinatum was detected in 27 out of 30 air samplings carried out over one year. The samplings with no F. circinatum detection were noted on 4 May, 6 July, and 14 September. No clear temporal trends were detected. The highest $\mathrm{CN}$ $\left(3.28 \times 10^{7}\right)$ was recorded on 27 July, but relatively high values of $\mathrm{CN}$ were detected across almost the entire sampling year. During 12 out of the 30 samplings, rain water was collected; six of the water samples were positive. Two negative water sample results confirmed the absence of the inoculum on 6 July and 14 September; however, on 4 May, the inoculum was detected in the water sample and not in the tape of the spore trap.

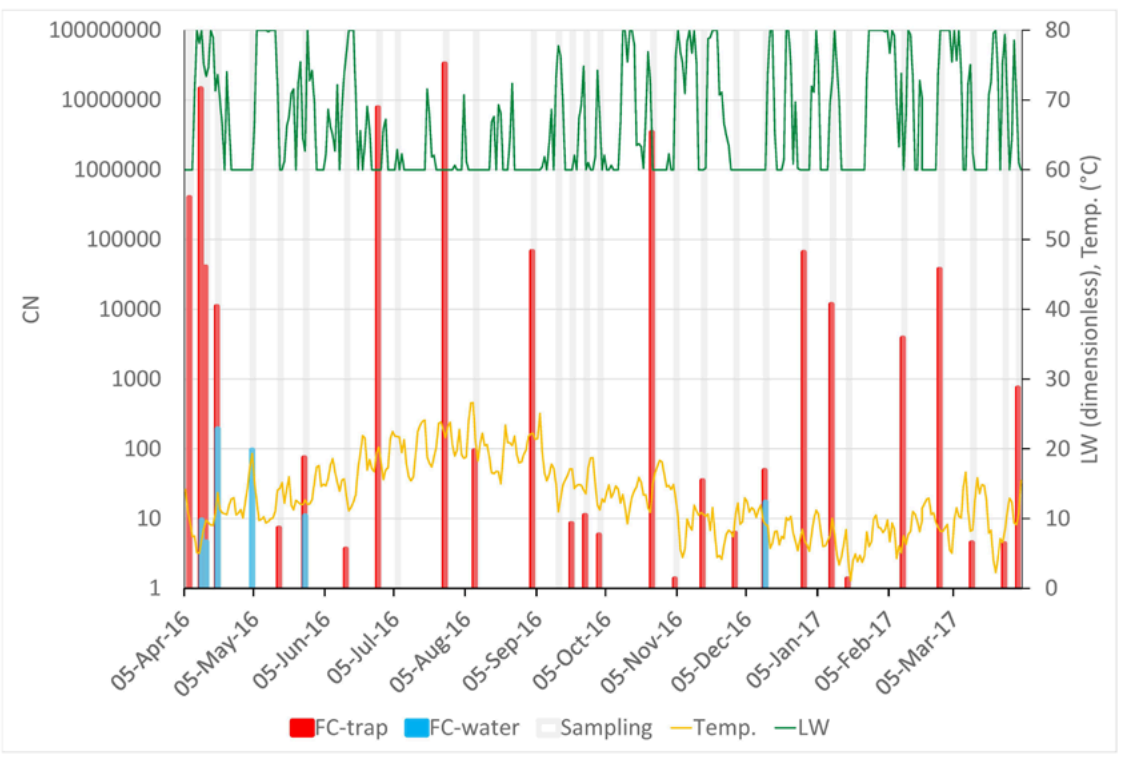

Figure 2. Variation of meteorological variables and abundance of Fusarim circinatum spores across the whole sampling year. The X-axis shows the progress of time. "FC-trap" values (left Y-axis, red columns) display the number of copies of the target sequence in $1 \mu \mathrm{L}$ of template DNA $(\mathrm{CN})$ in a logarithmic scale and reflect the amount of F. circinatum inoculum trapped by the rotating arm spore trap. "FC-water" values (left Y-axis, blue columns) display the $\mathrm{CN}$ detected in the samples of rain water. Grey columns mark the 30 sampling periods across the whole year. Temperature ("Temp.", yellow line, ${ }^{\circ} \mathrm{C}$ ) and leaf wetness ("LW", green line, scaleless; $60=$ dry, $80=$ absolutely wet) are shown on an average daily basis and scaled by the right $\mathrm{Y}$-axis. 
Significant correlations between $\mathrm{CN}$ and meteorological variables were found only for the air temperature and leaf wetness (Figure 3). The highest correlation $(\rho=-0.626, N=30, p<0.05)$ was found between $\mathrm{CN}$ and average air temperature during the 28 days before the end of the sampling period.

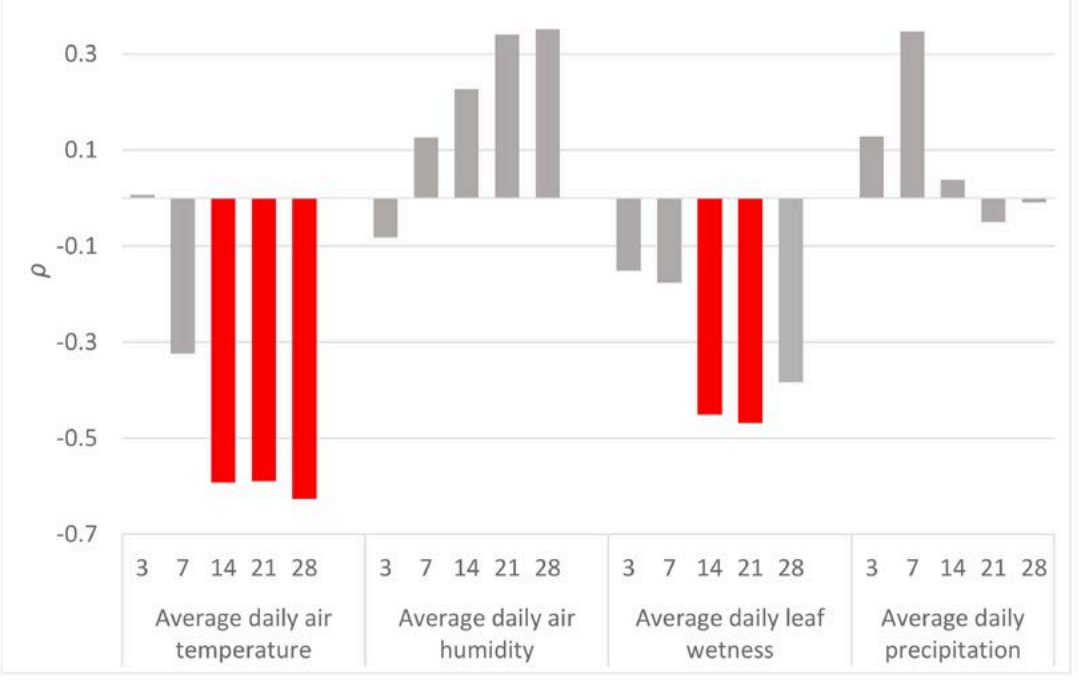

Figure 3. Spearman's correlation coefficients $(\rho)$ between the amount of the detected inoculum in the air samples $(\mathrm{CN})$ and meteorological variables (air temperature, air humidity, leaf wetness and precipitation). For each meteorological variable, daily values were averaged across the 3, 7, 14, 21 and 28 days before the end of each spore sampling. Significant correlation coefficients are displayed in red.

\subsection{Spatial Spore Dispersal}

All four samplings showed positive detection of F. circinatum, although for each sampling the amount of spores was very variable across the 11 traps, and, on average, the inoculum levels were fairly low. The highest $\mathrm{CN}$ detected was $6.48 \times 10^{2}$, recorded during the first sampling in the spot sited $100 \mathrm{~m}$ from the infested stand following the wind direction.

The $\mathrm{CN}$ values of the spatial dispersal study are displayed in Figure 4, which shows a map of the sampled area including the arrangement of the sampling spots, wind direction and speed. During all four samplings, the wind speed never exceeded $5 \mathrm{~m} \cdot \mathrm{s}^{-1}$ and the direction was very variable. In the first sampling, the wind was blowing $1-5 \mathrm{~m} \cdot \mathrm{s}^{-1}$ to the $S E$ and $E$ and highly positive detections were recorded 100 and $1000 \mathrm{~m}$ from the infested stand in the SE direction. Another positive, but lower value was noted $50 \mathrm{~m}$ from the stand in the opposite direction. The second sampling showed slightly ambiguous results. The wind was changing and blowing in SW and SE directions at a speed of $5 \mathrm{~m} \cdot \mathrm{s}^{-1}$. Positive values were recorded in all the directions, except NE, $1000 \mathrm{~m}$ from the stand. The same wind speeds and directions were also measured during the third sampling. In this case, the detected $\mathrm{CN}$ values were very low, but at $500 \mathrm{~m}$ in the opposite direction to the wind direction (NE and NW), the inoculum detection was negative. The last sampling was characterised by a very low wind speed of around $3 \mathrm{~m} \cdot \mathrm{s}^{-1}$ and changes of directions to $\mathrm{E}$ and $\mathrm{W}$. In this case, the inoculum was detected only at close distances to the infested stand and $500 \mathrm{~m}$ in the NE direction. All the $\mathrm{CN}$ values were very low (up to 10.9). 


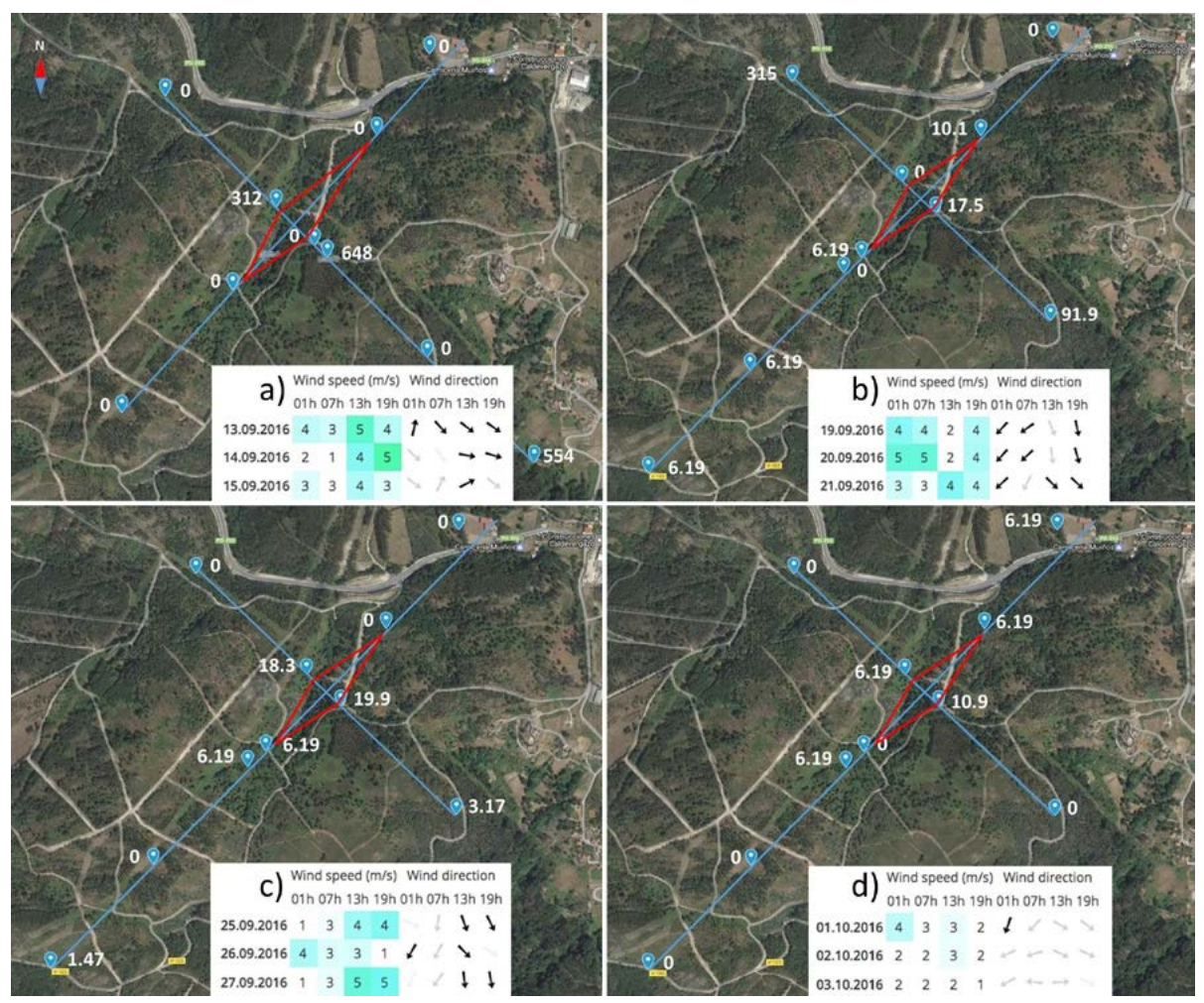

Figure 4. Results of the F. circinatum spore trapping for analysing the spatial patterns of inoculum dispersal. The four panels correspond to the four samplings carried out (13-15 September (a), 19-21 September (b), 25-27 September (c), 1-3 October (d)). For each sampling period, traps (blue drops) were established following a Latin cross arrangement (blue line) with the longest line following the forecasted wind direction (NW in a, and NE in b, c, and d) (see more details in the main text). Within each panel, the white numbers show the copies of the target sequence in $1 \mathrm{uL}$ of template DNA $(\mathrm{CN})$ detected by the rotating arm spore traps. The red continuous line connects the crosses of the four axes with the border of the infested stand (i.e., the limit of the infested stand in each orthogonal direction). Tables at the bottom of each panel reflect the real wind speed and direction measured during each sampling period.

\section{Discussion}

Results from the present paper indicate that F. circinatum can disperse in Galicia (NW Spain) over the whole year. Air sampling by the rotating arm spore traps detected the presence of F. circinatum spores in almost all of the 30 samplings across all seasons, but no clear temporal patterns were observed. Abundance of F. circinatum spores was, however, significantly related to the preceding weather conditions, with mean air temperature and mean leaf wetness negatively affecting the dispersal of the fungus. Spatial patterns of spore dispersal were also poorly defined, with no clear evidence of the effect of the predominating winds. Nevertheless, results presented here indicated that light breezes of just $5 \mathrm{~m} \cdot \mathrm{s}^{-1}$ can promote spore dispersal up to distances of at least $1000 \mathrm{~m}$. Altogether, results from the present study shed light on the natural dispersal of F. circinatum from infested stands in Europe and can contribute towards fine tuning appropriate methods to prevent the spread of this important pine disease. Although the results presented here come from just a one-year sampling period, the temperature and precipitation during the course of the experiment were representative of those typically found in the area in the last twelve years. A comparison of climatic data with historical averages indicates, however, that the sampling period included a slightly colder spring and autumn, and a relatively wetter spring. However, deviations from historical averages were within the normal range of the year-to-year variation that is typically observed in the region. 


\subsection{Rotating Arm Spore Traps-Efficient Tool for the Detection of Fusarium circinatum}

Garbelotto et al. [28] first applied a passive air sampling system using filter paper to collect deposited spores of F. circinatum. These authors suggested, however, the use of active air sampling spore traps to obtain more precise results in aerobiological studies of the inoculum of F. circinatum, especially for the study of its spatial spore dispersal. Here, we used, for the first time, rotating arm spore traps that actively sampled the F. circinatum spores, increasing the amount of air sampled per unit of time.

According to the amount of positive results from the whole year sampling shown in our study, the rotating arm spore traps combined with qPCR have been proven to be a reliable and efficient detection tool of the F. circinatum air inoculum. This type of air sampler has been successfully used in a number of studies focused on the detection of fungal pathogens' airborne inoculum. Recently, it has been used by Chandelier et al. [34] and Dvořák et al. [35] for the detection of Ash dieback pathogen, and by Choudhury et al. [36] for the detection of powdery mildew on spinach. The use of rotating arm spore traps is often limited by their inability to impact very small particles [37,38]. Too small particles, being blown by the air pillow generated by the rotation of the impactor, can pass around it [38]. Using Noll's equation [32], ROTTRAP 120 was calculated to be reliably efficient for particles of spherical diameter of at least $7.18 \mu \mathrm{m}$. Microconidia of F. circinatum are known to measure, on average, $9.7 \times 3.2 \mu \mathrm{m}$ and macroconidia $38.2 \times 3.6 \mu \mathrm{m}$ [1]. Therefore, part of the inoculum might not be sampled. Particularly, those microconidia facing the impactor at its narrow side might be blown around, so ROTTRAP 120 may underestimate the real amount of F. circinatum spores. Despite this disadvantage, the spore traps were able to catch the inoculum in $90 \%$ of the whole year samplings, reaching notable concentrations of the F. circinatum inoculum (up to $\mathrm{CN}$ of $10^{7}$ ).

\subsection{Seasonal Spore Dispersal}

The constant occurrence of the inoculum of F. circinatum (27 positive samplings out of 30) confirms that F. circinatum persists in the area of Galicia with a notable level throughout the whole year. Similar results with the constant presence of F. circinatum throughout the whole year were obtained in other areas such as northern California [28] and South Africa [39]. This finding means that F. circinatum in Galicia can develop the infection at any time of the year whenever suitable environmental conditions and susceptible hosts are available for spore germination, as was expected from the calculation of models of spread $[26,40]$.

The amount of inoculum expressed as $\mathrm{CN}$ varied during the year, oscillating between low and high values, but no clear temporal trends were observed. The most striking difference was noted in July, when the sampling at the beginning of July was negative and the sampling at the end of the month showed a positive result with the highest value of the year. Similar patterns were shown by Garbelotto et al. [28] in San Francisco in July-August. However, results of the present study are not reliably comparable with those of Garbelotto et al. [28] due to the length of the sampling time, which was two weeks and continuous in the American study and $48 \mathrm{~h}$ twice a month in ours.

\subsection{Effect of the Meteorological Conditions}

The influence of the weather on the inoculum occurrence was estimated via the correlation between the meteorological variables and the CN. The meteorological variables were included as averages across a certain amount of days before the end of each sampling.

Results indicated neither significant correlations between the $\mathrm{CN}$ and the preceding precipitation $(3,7,14,21$ and 28 days before sampling), nor with the air humidity. These results disagree with those reported by Garbelotto et al. [28], who found a positive relation between the precipitation and the trapping frequency. A possible explanation of this incongruence may be related to the contrasting spore trapping mechanisms used in the two studies. The spore traps used here sample the particles occurring directly in the air by impaction on the adhesive surface, while the passive spore traps used 
by Garbelotto et al. [28] and in other research [18,39] sample the spores passively deposited on a filter paper. Passive deposition may be supported by rainfall, as the rain drops trap the air inoculum and deliver it onto the surface of the filter paper. Therefore, that type of air sampling may overestimate the amount of inoculum in the air during rainy periods, favouring the positive correlation between precipitation and trapping frequency. Accordingly, half of our water rain samples were positive, evidencing the ability of the raindrops to collect the spores of F. circinatum.

The air temperature was determined as the factor most significantly correlated with F. circinatum spore abundance. The strongest correlation was found for the average of temperatures of the previous 28 days $(\rho=-0.63, N=30, p<0.05)$, although the last 14 days $(\rho=-0.59, N=30, p<0.05)$ and 21 days $(\rho=-0.59, N=30, p<0.05)$ were also significant. These negative correlation coefficients may be due to the pathogen's demand of lower temperatures or/and the limiting effect of extremely high temperatures for developing fruiting structures (phialides and sporodochia), followed by conidial production in the next 14-28 days. The preferences of the F. circinatum's inoculum for lower temperatures were also pointed out by Garbelotto et al. [28], who observed a higher amount of inoculum during the coldest period of the year from November to March. These authors also suggested that the minimum temperature of sporulation is around $0{ }^{\circ} \mathrm{C}$. Such temperatures are rare in the region of Galicia. During our monitoring, the minimal temperature dropped below zero for only a few hours for five days. The lowest recorded temperature during the whole year was $-3.4{ }^{\circ} \mathrm{C}$, which was recorded on 19 January during one of the samplings with a positive but extremely low $\mathrm{CN}=1.36$. This value was the lowest $\mathrm{CN}$ detected throughout the whole year, apart from the three zero values. Therefore, our results also confirm that too low temperatures are a limiting factor of F. circinatum sporulation. The negative influence of temperature on spore production is apparently opposite to the ability of spores to germinate. Inman et al. [41] revealed that, at $10^{\circ} \mathrm{C}$, the germination of spores is limited to around $10 \%$, being more than $70 \%$ at $15^{\circ} \mathrm{C}$ and more than $90 \%$ at $20^{\circ} \mathrm{C}$.

Leaf wetness (LW) was calculated as the second most correlated meteorological variable with F. circinatum spore abundance. Leaf wetness is an important variable which specifically affects the fungal growth and fructification of F. circinatum on the plant surfaces $[35,42,43]$. This variable was significantly correlated with precipitation $(\rho=0.83, N=337, p<0.05)$ and apart from the wetness caused by rainfall, it also records the occurrence of dew, condensation from fog, etc. As occurred with the air temperature, its effect was negative and delayed two $(\rho=-0.45, N=30, p<0.05)$ to three $(\rho=-0.47, N=30, p<0.05)$ weeks before sampling. The presence of water on the host surface seems, thus, to be unfavourable for the fructification structures' development. Again, conditions for sporulation appear to be opposite to those needed for spore germination [44], creating a putative obstacle for the disease spread.

The correlation analysis carried out in the present study can be biased by some other disturbing factors related to the construction of the spore trap. Particularly, the impactors with the adhesive tape are not protected from the rain and, therefore, some particles that are already trapped may be washed out by rain showers. However, according to the results of the correlation analyses, this does not seem to be happening, as there was not a significant correlation between the $\mathrm{CN}$ and the precipitations over the past 3 days (including the duration of the sampling).

\subsection{Spatial Spore Dispersal}

Unfortunately, the inoculum levels in the air during the period of this survey were very low in comparison with the rest of the samplings over the whole year. Nevertheless, results allowed some conclusions to be inferred about the spatial spread of the inoculum.

Although the relationship between spore occurrence and the predominant wind was not very clear, the influence of the wind speed was apparent. Light breezes of just $5 \mathrm{~m} \cdot \mathrm{s}^{-1}$ can promote spore dispersal up to distances of at least $1000 \mathrm{~m} \cdot \mathrm{s}^{-1}$. In the case of such winds (three samplings out of four), the spore trap distanced at $1000 \mathrm{~m}$ detected amounts of inoculum similar to those at $50 \mathrm{~m}$ distance. A similar result was found by Garbelotto et al. [28], who did not find significant differences between 
trapping frequencies 100, 200 and $300 \mathrm{~m}$ from the putative source of the inoculum. These authors did not confirm any differences in the inoculum levels due to the wind direction. They explained this lack of relationship by the long duration of the sampling period (two weeks per sampling), which makes the result insensitive to short-term wind direction changes. In our work, we are also unable to provide any statistical support for our observations due to the changing wind direction, the low amount of inoculum detected during the sampling periods, and the low wind speed in some of the samplings. Additionally, the geomorphology of the sampled area is very diverse, which leads to particular local air currents spreading the air inoculum, and the wind direction data and speed were downloaded for a locality $15 \mathrm{~km}$ from the sampled area. Results regarding the influence of wind direction and speed on F. circinatum spore dispersal should be, thus, managed with care.

\section{Conclusions}

Monterey pine forests in Galicia are strongly endangered by the natural spread of F. circinatum. The results of this one-year study indicated that the air inoculum was available throughout the whole year, with only very few exceptions. Lower temperatures and less humidity on the host surface caused by precipitation or cloud-water interception are more suitable for the pathogen to develop higher amounts of inoculum. Masses of inoculum can be transferred by winds of just $5 \mathrm{~m} \cdot \mathrm{s}^{-1}$ for distances of at least one kilometre. This last conclusion, however, should be managed with care as wind speed and details on wind directions within the sampling area were not accurately measured, and just inferred from nearby weather stations. Rotating arm spore traps combined with qPCR detection are a reliable method for the detection of F. circinatum spores.

Acknowledgments: This work was funded by a research project of Ministry of education, youth and sports of the Czech Republic LD15046 "Detection and biology of Gibberella circinata-essentials for early warning and management strategies in the Czech Republic" and Short Term Scientific Missions of COST Action FP1406-Pine pitch canker-strategies for management of Gibberella circinata in greenhouses and forests (PINESTRENGTH). The authors thank Agustin Blond and José de la Fuente (Forest Service, Xunta de Galicia) for helping in locating the stand, and María de la Fuente for valuable comments on early drafts of the manuscript. We are also thankful to Dr. Renaud Ioos (Laboratoire National de la Protection des Végétaux, Malzéville, France) for providing us the plasmid as a cooperation within COST Action FP1406.

Author Contributions: M.D. conceived the study, designed and performed the field experiments, extracted DNA, analysed data and wrote the article; P.J. performed the field experiment; L.B. conceived the study and wrote the article; G.R. optimized and performed the qPCR analysis; R.Z. proposed the experimental area, performed the field surveys and wrote the article.

Conflicts of Interest: The authors declare no conflict of interest.

\section{References}

1. Nirenberg, H.I.; O'Donnell, K. New Fusarium species and combinations within the Gibberella fujikuroi species complex. Mycologia 1998, 90, 434-458. [CrossRef]

2. Gordon, T.R. Pitch canker. In Infectious Forest Diseases; Gonthier, P., Nicolotti, G.I., Eds.; CAB International: London, UK, 2013.

3. Barnard, E.L.; Blakeslee, G.M. Pitch Canker of Southern Pines; Florida Department of Agriculture \& Consumer Services, Division of Plant Industry: Gainesville, FL, USA, 1987.

4. Dwinell, L.D.; Barrows-Broaddus, J.B.; Kuhlman, E.G. Pitch canker: A disease complex. Plant Dis. 1985, 69, 270-276. [CrossRef]

5. Britz, H.; Couhnho, T.A.; Gordon, T.R.; Wingfield, M.J. Characterisation of the pitch canker fungus, Fusarium circinatum, from Mexico. S. Afr. J. Bot. 2001, 67, 609-614. [CrossRef]

6. Hepting, G.H.; Roth, E.R. Pitch canker, a new disease of some southern pines. J. For. 1946, 44, 742-744.

7. Kobayashi, T. Pitch canker of Pinus luchuensis, a new disease in Japanese forest. For. Pests 1989, 38, $169-173$.

8. Viljoen, A.; Wingfield, M.J.; Marasas, W.F.O. First report of Fusarium subglutinans f. sp. pini on pine seedlings in South Africa. Plant Dis. 1994, 78, 309-312. [CrossRef]

9. Lee, J.-K.; Lee, S.-H.; Sung-II, Y.; Lee, Y.-W. First report of pitch canker disease on Pinus rigida in Korea. Plant Pathol. J. 2000, 16, 52-54. 
10. Wingfield, M.J.; Jacobs, A.; Coutinho, T.A.; Ahumada, R.; Wingfield, B.D. First report of the pitch canker fungus, Fusarium circinatum, on pines in Chile. Plant Pathol. 2002, 51, 397. [CrossRef]

11. Landeras, E.; García, P.; Fernández, Y.; Braña, M.; Fernández-Alonso, O.; Méndez-Lodos, S.; Pérez-Sierra, A.; León, M.; Abad-Campos, P.; Berbegal, M.; et al. Outbreak of pitch canker caused by Fusarium circinatum on Pinus spp. in northern Spain. Plant Dis. 2005, 89, 1015. [CrossRef]

12. Dwinell, D. Global Distribution of the Pitch Canker Fungus; United States Department of Agriculture: Salt Lake City, UT, USA, 1999; pp. 54-57.

13. EPPO Global Database. First Report of Gibberella Circinata in France; EPPO: Paris, France, 2006; p. 104.

14. Carlucci, A.; Colatruglio, L.; Frisullo, S. First report of Pitch Canker caused by Fusarium circinatum on Pinus halepensis and P. pinea in Apulia (southern Italy). Plant Dis. 2007, 91, 1683. [CrossRef]

15. Bragança, H.; Diogo, E.; Moniz, F.; Amaro, P. First report of pitch canker on pines caused by Fusarium circinatum in Portugal. Plant Dis. 2009, 93, 1079. [CrossRef]

16. EPPO Global Database. Gibberella Circinata; EPPO: Paris, France, 2005; pp. 383-386.

17. EPPO Global Database. Fusarium Circinatum (GIBBCI): Distribution; EPPO: Paris, France, 2017.

18. Schweigkofler, W.; O'Donnell, K.; Garbelotto, M. Detection and quantification of airborne conidia of Fusarium circinatum, the causal agent of pine pitch canker, from two California sites by using a real-time PCR approach combined with a simple spore trapping method. Appl. Environ. Microbiol. 2004, 70, 3512-3520. [CrossRef] [PubMed]

19. Gordon, T.R. Biology and management of Gibberella circinata, the cause of pitch canker in pines. Control Fusarium Dis. Res. Sign Post Kerala India 2011, 217-232.

20. Gordon, T.R.; Storer, A.J.; Wood, D.L. The pitch canker epidemic in California. Plant Dis. 2001, 85, 1128-1139. [CrossRef]

21. Gordon, T.R. Pitch canker disease of pines. Phytopathology 2006, 96, 657-659. [CrossRef] [PubMed]

22. Sakamoto, J.M. Exploring the Roles of Environmental Factors and the Twig Beetle, Pityophthorus spp. (Coleoptera: Scolytidae) in the Epidemiology of Pitch Canker of Pinus radiata; University of California: Davis, CA, USA, 2004.

23. Möykkynen, T.; Capretti, P.; Pukkala, T. Modelling the potential spread of Fusarium circinatum, the causal agent of pitch canker in Europe. Ann. For. Sci. 2015, 72, 169-181. [CrossRef]

24. Gonthier, P.; Garbelotto, M.M.; Nicolotti, G. Seasonal patterns of spore deposition of heterobasidion species in four forests of the Western alps. Phytopathology 2005, 95, 759-767. [CrossRef] [PubMed]

25. Ganthaler, A.; Mayr, S. Temporal variation in airborne spore concentration of Chrysomyxa rhododendri: Correlation with weather conditions and consequences for Norway spruce infection. For. Pathol. 2015, 45, 443-449. [CrossRef]

26. Ganley, R.J.; Watt, M.S.; Manning, L.; Iturritxa, E. A global climatic risk assessment of pitch canker disease. Can. J. For. Res. 2009, 39, 2246-2256. [CrossRef]

27. Woods, A.J.; Martín-García, J.; Bulman, L.; Vasconcelos, M.W.; Boberg, J.; La Porta, N.; Peredo, H.; Vergara, G.; Ahumada, R.; Brown, A.; et al. Dothistroma needle blight, weather and possible climatic triggers for the disease's recent emergence. For. Pathol. 2016, 46, 443-452. [CrossRef]

28. Garbelotto, M.; Smith, T.; Schweigkofler, W. Variation in rates of spore deposition of Fusarium circinatum, the causal agent of pine pitch canker, over a 12-month-period at two locations in northern California. Phytopathology 2008, 98, 137-143. [CrossRef] [PubMed]

29. Wingfield, M.J.; Hammerbacher, A.; Ganley, R.J.; Steenkamp, E.T.; Gordon, T.R.; Wingfield, B.D.; Coutinho, T.A. Pitch canker caused by Fusarium circinatum-A growing threat to pine plantations and forests worldwide. Australas. Plant Pathol. 2008, 37, 319-334. [CrossRef]

30. Perkins, W.A.; Leighton, P.A. The rotorod sampler. In Second Semi-Annual Report No. CML 186; Aerosol Laboratory: Vancouver, BC, Canada, 1957.

31. McCartney, H.A.; Fitt, B.D.L.; Schmechel, D. Sampling bioaerosols in plant pathology. J. Aerosol Sci. 1997, 28, 349-364. [CrossRef]

32. Noll, K.E. A rotary inertial impactor for sampling giant particles in the atmosphere. Atmos. Environ. 1970, 4, 9-19. [CrossRef]

33. Ioos, R.; Fourrier, C.; Iancu, G.; Gordon, T.R. Sensitive detection of Fusarium circinatum in pine seed by combining an enrichment procedure with a real-time polymerase chain reaction using dual-labeled probe chemistry. Phytopathology 2009, 99, 582-590. [CrossRef] [PubMed] 
34. Chandelier, A.; Helson, M.; Dvorak, M.; Gischer, F. Detection and quantification of airborne inoculum of Hymenoscyphus pseudoalbidus using real-time PCR assays. Plant Pathol. 2014. [CrossRef]

35. Dvořák, M.; Rotkova, G.; Botella, L. Detection of airborne inoculum of Hymenoscyphus fraxineus and H. albidus during seasonal fluctuations associated with absence of apothecia. Forests 2016, 7, 1. [CrossRef]

36. Choudhury, R.A.; Koike, S.T.; Fox, A.D.; Anchieta, A.; Subbarao, K.V.; Klosterman, S.J.; Mcroberts, N. Spatiotemporal patterns in the airborne dispersal of spinach downy mildew. Phytopathology 2016, 107, 50-58. [CrossRef] [PubMed]

37. Dhingra, D.D.; Sinclair, J.B. Basic Plant Pathology Methods; CRC Press Inc.: Boca, FL, USA, 1985.

38. Kennedy, R. The Air Spora-A Manual for Catching and Identifying Airborne Biological ParticlesBy Maureen E. Lacey and Jonathan S. West. Plant Pathol. 2007, 56, 547-548. [CrossRef]

39. Fourie, G.; Wingfield, M.J.; Wingfield, B.D.; Jones, N.B.; Morris, A.R.; Steenkamp, E.T. Culture-independent detection and quantification of Fusarium circinatum in a pine-producing seedling nursery. South. For. J. For. Sci. 2014, 76, 137-143. [CrossRef]

40. Baker, R.; Candresse, T.; Simon, E.; Gilioli, G.; Grégoire, J.; Jeger, M.J.; Karadjova, O.E.; Lövei, G.; Puglia Porta, A.; Rafoss, T.; et al. Risk assessment of Gibberella circinata for the EU territory and identification and evaluation of risk management options. Eur. Food Saf. Auth. 2010, 8, 1-93. [CrossRef]

41. Inman, A.R.; Kirkpatrick, S.C.; Gordon, T.R.; Pathology, P.; Shaw, D.V. Limiting effects of low temperature on growth and spore germination in Gibberella circinata, the cause of pitch canker in pine species. Plant Dis. 2008, 92, 542-545. [CrossRef]

42. Mathieu, D.; Kushalappa, A.C. Effects of temperature and leaf wetness duration on the infection of celery by Septoria apiicola. Phytopathology 1993, 83, 1036-1040. [CrossRef]

43. Villalta, O.N.; Washington, W.S.; Rimmington, G.M.; Taylor, P.A. Effects of temperature and leaf wetness duration on infection of pear leaves by Venturia pirina. Aust. J. Agric. Res. 2000, 51, 97-106. [CrossRef]

44. Bradley, D.J.; Gilbert, G.S.; Parker, I.M. Susceptibility of clover species to fungal infection: The interaction of leaf surface traits and environment. Am. J. Bot. 2003, 90, 857-864. [CrossRef] [PubMed] 